\title{
Circulating biomarkers in schizophrenia: a proteomics perspective
}

\author{
Cátia Santa ${ }^{1,2}$, Joana F. Coelho ${ }^{1,3}$, Nuno Madeira ${ }^{3,4}$ and Bruno Manadas ${ }^{1}$ \\ Special Issue on the Neurobiology of Mental IIIness
}

\begin{abstract}
Schizophrenia (SCZ) is one of the most severe and devastating major mental disorders, with an onset typically in late adolescence or early adulthood affecting about $0.5-1.2 \%$ of the population worldwide. It is one of the most debilitating medical conditions, with striking socio-economic burden to society due to lost employment and social support that largely surpass direct costs of treatment. SCZ is listed by the World Health Organization (WHO) among the top 20 leading causes of disability worldwide. Its diagnosis is syndromic, based in clinical interviewing and anamnesis, as there is to date no biochemical test to aid in this diagnosis. On the other hand, SCZ treatment is mostly based in antipsychotic drugs which are in several aspects somehow ineffective, and some of these medications have low tolerability with severe side effects. For all these reasons, the current search for new panels of biomarkers is of the utmost importance to aid in the correct diagnosis and stratification of the patients, prognosis, and prediction of treatment effectiveness.

In this review, a total of 25 publications on peripheral SCZ biomarkers are presented from proteomics studies performed in body fluids of patients searching for protein markers, and using mass spectrometry. To date such proteomics studies have already been achieved in cerebrospinal fluid (CSF), serum, plasma, peripheral blood cells (namely, mononuclear cells, T-cells and red blood cells), saliva, and sweat, being of paramount importance in the schizophrenia research field, but still lacking validation and clinical translation.

In summary, a general overview of the results from these 25 studies, as well as the challenges and future perspectives of the field, are presented and discussed.
\end{abstract}

Keywords: Schizophrenia, Biomarkers, Proteomics, Mass Spectrometry.

${ }^{1} \mathrm{CNC}$ - Center for Neuroscience and Cell Biology, University of Coimbra, Portugal

${ }^{2}$ III - Institute for Interdisciplinary Research, University of Coimbra, Portugal ${ }^{3}$ Faculty of Medicine of the University of Coimbra, University of Coimbra, Portugal

${ }^{4}$ Psychiatry Department, Coimbra Hospital and University Centre, Portugal
Citation: Santa et al. Circulating biomarkers in schizophrenia: a proteomics perspective. International Journal of Clinical Neurosciences and Mental Health 2017; 4(Suppl. 3):S05

DOI: https://doi.org/10.21035/ijcnmh.2017.4(Suppl.3).S05

Published: 15 Nov 2017

\section{Correspondence: Bruno Manadas}

Center for Neuroscience and Cell Biology - University of Coimbra

UC Biotech - Parque Tecnológico de Cantanhede, Núcleo 04, Lote 8 3060-197

Cantanhede - Portugal

Email: bmanadas@gmail.com 


\section{Introduction}

Schizophrenia (SCZ) is categorized as a psychotic disorder, being one of the more debilitating major mental disorders [1]. Its socio-economic burden to society is enormous, being listed by the World Health Organization (WHO) among the top 20 leading causes of disability worldwide [2].

This disorder is characterized by a chronic and frequently deteriorating course with a prevalence of $0.5-1.2 \%$ of the population worldwide [3]. Usually, its onset occurs in late adolescence or adulthood, although rare infant and late-onset cases have been reported, and is frequently preceded by a prodromal phase with a variable duration $[1,4]$.

SCZ has substantial clinical heterogeneity, with considerable symptomatic variation between patients, and is characterized by a diverse set of symptoms: (i) positive, such as delusions, hallucinations or thought disorder; (ii) negative, as affective flattening, reduced interest and motivation and also social withdrawal; (iii) cognitive dysfunction symptoms, as impaired attention, learning and memory; where positive symptoms tend to relapse and remit, negative and cognitive symptoms tend to be chronic and the main drivers of patients' poor social functioning [4].

Like many common diseases SCZ is complex and multifactorial, with contributions from multiple susceptibility genetic variants and environmental factors [1]. Yet, studies of its heritability are complicated by locus heterogeneity, imprecise phenotypic definitions, incomplete penetrance and interaction with non-genetic factors. Thus, our understanding of the pathogenesis and neurobiology of the disorder remains fragmented and incomplete.

Diagnosis is only made after a first psychotic episode, based in descriptive criteria, and may be considered clinician-dependent as there is to date no biochemical test to aid in this diagnosis. On the other hand, SCZ treatment is mostly based in antipsychotic drugs which are substantially ineffective in about $40 \%$ of the patients even in a first episode; unsurprisingly, around $60 \%$ of patients end up quitting treatment due to lack of efficacy and/or severe side effects $[5,6]$. Thus, in the context of current research on the pathophysiology of SCZ, the search for new biomarkers, especially in body fluids, is of paramount importance to aid in the correct diagnosis and stratification of the patients.

In this review, we aim to examine the publications on peripheral SCZ biomarkers published until date, in particular studies on proteomics, searching for protein markers, using the leading non-target technique for discovery of the field: mass spectrometry. Also, a critical view on the future perspectives of the field in what concerns expected results and new technical developments are presented.

\section{The need for biomarkers in psychosis}

The diagnosis of SCZ is made with information collected in clinical interviewing, using an unstructured clinical approach or by mean of structured diagnostic tools built around the criteria of main diagnostic systems. Diagnosis is then achieved by verifying the fulfillment of a number of operational criteria specified in international classification systems such as the Diagnostic and Statistical Manual of Mental Disorders, 5th edition (DSM-5)[7] or the International Classification of Diseases, 10th revision (ICD-10) [8]. The diagnosis of SCZ remains essentially descriptive based on operational criteria that are not pathognomonic and whose validity is doubtful. Thus, these criteria cannot clearly define the diagnostic boundaries of this nosologic entity, demarcating it with certainty from other categories of non-affective or even affective psychoses.

In fact, psychiatry remains one of the few areas of medicine that does not use routine laboratory tests for diagnostic purposes, mainly due to the fact that the biology of the diseases is poorly known, their preclinical models present many challenges and drawbacks, and specially due to the fact that the brain is not easily accessible [9]. Thus, schizophrenia remains a syndromic concept with frail validity, and it has been argued by many that such weaknesses involving the imprecisions of its diagnostic procedures and phenotypic definition have been an impediment for research in this area [10].

In psychiatric practice a biomarker (or panel of biomarkers) may be useful: (i) to correctly diagnose and stratify a psychiatric patient, in a field where several diseases may have overlapping clinical symptoms, or even (ii) to better classify at-risk individuals; (iii) it may also be used for prognosis or (iv) as therapeutic monitoring, and (v) predictive of therapy compliance $[9,11,12]$. In summary, the definition of a biomarker states that it should be a quantifiable or identifiable physical characteristic that is closely and exclusively related to a given physiological state. This way, biomarkers can be used to assess physiological conditions, such as good health or disease, toxicity or drug treatment responses [13].

Throughout the years many research groups have been studying SCZ with numerous and varied strategies. In the genetics field studies have been performed using: genome wide association studies (GWAS), next-generation sequencing, copy-number variations (CNV) and microarrays, with different study designs using the general population, twins and family studies [14, 15] linking SCZ with rare genetic variations, stating that SCZ has a strong genetic component. The heritability is estimated to be close to $80 \%$, although the heterogeneous manifestations of the disease and its complex genetic architecture indicate a non-mendelian complex mode of transmission $[15,16]$.

Many years and numerous studies later, more than 100 distinct loci containing fairly common alleles of small effect are now known to exist [17]; several copy number variants that may individually confer an elevated risk for schizophrenia have also been identified [18] (for a review on the subject refer to [19]). Thus, it is clear that there is a substantial contribution of genetic factors for the pathophysiology of schizophrenia, but it is also understood that 
this contribution is not able to fully explain its etiology. While the complexity of the subject is well accepted, it is believed that much of the genetic risk for schizophrenia is still to be uncovered and the majority of genetic findings still do not have a clinical application [1]. Nonetheless some authors have already suggested that chromosomal microarray analysis of clinically relevant CNVs, with a prevalence of around 5\%, should be used as a clinical diagnostic test [20].

Given all this, a genetic trait associated with schizophrenia can give clues about increased risk and susceptibility for disease manifestation, but the molecular alterations or deficits are ultimately reflected in the phenotype, as in the proteome and metabolome [11]. The importance of certain environmental factors and insults are also well established as risk factors for schizophrenia $[21,22]$. The impact of these factors is difficult to anticipate with a genomic analysis, but they are reflected in the molecular phenotype. Moreover, the genome is static while the proteome and metabolome are dynamic $[12,23]$, making it possible to quantitatively track a molecule over time, therefore allowing to evaluate disease progression, correlating its levels with symptom severity or anticipating therapeutic outcomes.

Overall, it is possible to state that a need for biomarkers of psychiatric diseases at different levels (diagnosis, prognosis, treatment resistance...) is pressing and that to achieve this not only gene expression and DNA variations should be studied and determined, but also the abundance and modifications of the proteins and their distribution at the subcellular level [14]. In particular, efforts to find protein altered patterns in circulating fluids have increased interest given that such fluids are relatively easier to access than the brain in order to perform clinical testing but, firstly, to enable relevant research.

\section{Proteomics contribution for schizophrenia's biomarker research}

The term "proteomics" was firstly introduced in 1995 and it was used to define the large-scale analysis of the entire composition of proteins of a cell line, tissue, or organism [24]. Proteomics aims to describe and understand biological processes based on the qualitative or quantitative comparison of proteomes [14], especially in diseased versus control cases. The great development of this area may be attributed to the technological advances in mass spectrometry (MS), optimization in sample preparation and computer sciences that are now able to deal with the large amount of information that is nowadays generated by the MS-based technologies [25, 26]. With proteomic approaches, several levels of information may be obtained: (i) identification of the proteins in a sample at a given moment; (ii) expression levels of the proteins or quantitative proteomics; (iii) identification or quantification of post-translational modifications (PTM) of those proteins (phosphorylation, glycosylation, acetylation, ...); (iv) de- termination of protein-protein interactions; (v) proteomic functional studies to unravel to role of a protein, constituents of functional complexes its localization, translocation, among others [24, 26].

In the beginning of MS-based large screening proteomic approaches it was possible to characterize proteins in complex mixtures, but these studies were mainly qualitative; while successfully identifying a high amount of proteins from one sample they fail in quantifying expression levels[27]. Over the last few years the proteomics field has turned to quantitative approaches, especially due to technological advances, and this has become the analysis of choice when comparing proteomes, given that most of the biological changes of interest are slight differences in the amount of a protein present in a given situation and not an abrupt variation testifying its presence or absence [28].

These improvements in MS-based proteomics techniques have paved the way to reach the long wanted goal of having an exhaustive characterization of all proteomes at specific moments, especially in diseased states, from where biomarkers for diagnosis, prognosis or treatment could be identified, validated and introduced into clinical practice. This is where the proteomics field stands at the moment, being directed to clinical settings although it mainly remains in a discovery phase of biomarkers; in psychiatric research the status is not different [23].

The history of proteomics in schizophrenia research is very similar to the history of proteomics itself $[24,29]$. The first reports of untargeted proteomic large screenings in schizophrenia begun by using two-dimensional electrophoresis (2-DE) [30] where the first dimension is an isoelectric focusing step (IEF) followed by the second dimension which is a standard SDS-PAGE. In this approach the quantitative information is retrieved from the analysis of the intensity of the staining of a given spot in the gel, which is then picked, and the proteins are identified by MS. Later on, an improvement of this technology was introduced - two-dimensional difference gel electrophoresis (2D-DIGE) [31], where the separation steps remain the same but proteins are directly labelled with fluorescent dyes (CyDies), enabling the analysis of multiple samples in the same gel, this way improving the reproducibility of the quantitative results [32].

Although 2-DE techniques have been extremely important in transforming protein analysis into an "omics" approach, these methods have some drawbacks as the lengthy sample preparation and difficulty in detecting some subtypes of proteins, like membrane proteins, or due to dynamic range limitations [32]. Throughout the years researchers have turned to other methodologies that can measure quantitative levels of the entire set of proteins, and that can be divided into two main groups: (i) labelling techniques, which require the chemical, metabolic or enzymatic stable isotopic labelling of the samples prior to MS analysis; (ii) label-free techniques, which are gaining increasing interest due to improvements in accuracy and 
sensitivity of MS instruments and data processing algorithms [33].

All the above-mentioned methods are, in general, untargeted techniques aiming to identify and quantify all the proteins in a complex sample compared to another, usually diseased proteome versus control. Nonetheless, some of these methods may be used for targeted approaches or even for absolute quantification, being the gold standard of MS-based absolute quantification the multiple reaction monitoring (MRM) method [34].

There are numerous studies employing these techniques in psychiatric research. Initially, the great majority of the studies were performed in post-mortem brain tissue and it is easy to find large screenings in several brain areas, such as frontal [35] and prefrontal cortex [36]; the corpus callosum [37]; the temporal lobe [38] or the hippocampus [39] (citations as examples, for an extensive review refer to [14]). Later on, other tissues [40, 41] or cell populations [42] and body fluids (Tables 1 and 2) or even animal models (e.g. [43, 44]) started to raise interest in the search of the pathophysiological basis of this disease, but especially in the quest for biomarkers.

As SCZ is considered a brain disease a natural way of studying it would be through the brain, and when talking about proteomics this means post-mortem brain tissue [45], as above mentioned. Nonetheless, and although very informative, post-mortem brain tissue has its drawbacks, as the susceptibility of confounding factor, namely medication or age and chronicity of the disease, besides the fact that the tissue is static, with no possibilities of being manipulated, disturbed or having longitudinal samplings [46, 47]. Thus, current proteomic studies have been focusing in peripheral tissues or fluids, and integrating all these analyses a more complete picture of the disease is expected to emerge in what concerns onset, progression and responsiveness [47].

\section{Biomarker discovery in CSF}

It is expected that the quest for biomarkers may be performed as closely as possible to the source of the question being studied, and in what concerns neuropsychiatry (and neurology in general) and the diagnostic purpose of biomarker discovery, the closest to the living brain that it is possible to get is to analyze the cerebrospinal fluid (CSF)[11].

CSF, or liquor, is a body fluid that occupies the ventricular system surrounding the brain and the spinal cord, and is rich in molecules, such as proteins, peptides and small metabolites, that are either products of or have physiological properties in the central nervous system (CNS) [55, 56]. It is estimated that at a given time each person has 150 $\mathrm{mL}$ of CSF, with a daily production turn-over of $500 \mathrm{~mL}$, meaning that CSF is extremely dynamic and characteristic of the physiology at the moment of collection [11].

The protein content of CSF may be very variable and is estimated to have values between 0.18 to $0.58 \mathrm{~g} / \mathrm{L}$ [57], which corresponds to about $0.5 \%$ of the concentration of proteins in serum [58], and presents a high dynamic range with proteins like albumin accounting for much of the protein content [59]. Nonetheless, even the total amount of protein present in the CSF has diagnostic potential, for instance an increase in protein content in the liquor is observed in infection or multiple sclerosis [57].

CSF is collected by means of a lumbar puncture, where a small volume of the liquor is collected for clinical analysis (for instance for protein and glucose levels assessment, cell counts and microscopic examination, or culture) [57] and it can be collected using controlled and standardized procedures which help reducing variability at the collection step [59]. CSF collection is considered a fairly invasive procedure, implicating that new collections, either to have more sample volume or to perform longitudinal studies, are not easy to perform. Thus, proteomic analysis of CSF is feasible but implicates robust and sensitive techniques [11].

After a careful search in public repositories (namely PubMed and Web of Knowledge) and with bibliographic mining, we were able to locate 8 schizophrenia studies using MS-based proteomics approaches to study the CSF as documented in Table 1. From the analysis of this table it is possible to understand that the first study of the kind was performed in 2003, and that several studies followed until 2012. Since then we were not able to find other studies using mass spectrometry in CSF of schizophrenic patients.

The majority of these proteomic studies were performed using 2-DE followed by MALDI-TOF-MS [48, $50,53]$ or by using SELDI-TOF-MS [40, 49, 51, 54]. Only one study [52] uses label-free $\mathrm{MS}^{\mathrm{E}}$, an approach where the fragmentation spectra of virtually all the peptides resulting from protein digestion is acquired [60].

In general, a low number of proteins are identified in these studies, but some of the studies claim to be able to distinguish between schizophrenia and healthy groups using either the relative quantification of the detected features (exact mass and retention time) in $\mathrm{MS}^{\mathrm{E}}$ analysis [52]; or by using the up-regulation of a VGF-derived peptide and the down-regulation of transthyretin, in this case achieving a specificity of $95 \%$ and a sensitivity above $80 \%$ in distinguishing SCZ from controls, yet being unable to distinguish it from patients in the prodromal state [49]. Several other studies also proposed some molecules as SCZ biomarkers, such as Wan et al. [50], which proposes transthyretin and apolipoprotein $\mathrm{E}$ as possible markers for diagnosis and optimal treatments; or Martins-de-Souza and colleagues, which propose apolipoproteins $\mathrm{E}$ and A1 and prostaglandin- $\mathrm{H} 2 \mathrm{D}$-isomerase as a putative panel of biomarkers in CSF for SCZ diagnosis [53]. In another very complete study of CSF, apolipoprotein A1 was found to be down-regulated in CSF, liver, red blood cells (RBC), serum, and in post-mortem brain tissue regardless of the treatment and chronicity of the disease, evidencing that some alterations in CNS can have correlated results in systemic organs and fluids [40]. 
Table 1. Proteomic studies of schizophrenia and schizophrenia biomarker discovery using mass spectrometry in CSF.

\begin{tabular}{|c|c|c|c|c|c|c|c|c|c|}
\hline Year & $\begin{array}{l}\text { Number of } \\
\text { Samples }\end{array}$ & Method & Diagnosis & Treatment & No. proteins & Altered Proteins & $\begin{array}{l}\text { Altered } \\
\text { Pathways }\end{array}$ & Reference & Observations \\
\hline 2003 & $10 \mathrm{SCZ} ; 10 \mathrm{CTR}$ & 2-DE/MALDI-MS & Schizophrenia & - & Total ID: 54 & APOA4 $\downarrow$ & $\begin{array}{l}\text { Lipoprotein } \\
\text { metabolism }\end{array}$ & [48] & $\begin{array}{l}\text { Haptoglobin, fibrinogen, comple- } \\
\text { ment component } 3 \text { and Gc-globulin } \\
\text { were also altered, but not statistical } \\
\text { significant }\end{array}$ \\
\hline 2006 & $\begin{array}{l}58 \text { first-episode SCZ; } \\
16 \text { DEP; } 5 \text { OCD; } 10 \\
\text { AD; } 90 \text { CTR }\end{array}$ & SELDI-TOF-MS & $\begin{array}{l}\text { Paranoid schizo- } \\
\text { phrenia; Depres- } \\
\text { sion; Obsessive- } \\
\text { compulsive } \\
\text { disorder; Alzheim- } \\
\text { er's disease }\end{array}$ & Drug naive & - & $\begin{array}{l}\text { 40-amino acid } \\
\text { VGF32-62 peptide } \\
\uparrow \text { and TTHY } \downarrow\end{array}$ & - & [49] & $\begin{array}{l}\text { Different distribution between SCZ } \\
\text { and CTR; } 80 \% \text { sensitivity and } 95 \% \\
\text { specificity in the validation study }\end{array}$ \\
\hline 2006 & 35 SCZ; 36 CTR & 2-DE/MALDI-MS & Schizophrenia & Chlorpromazine & Total ID: 80 & $\begin{array}{l}\text { APOE } \downarrow ; \text { TTHY } \\
\text { tetramer } \downarrow ; \text { TRFE } \downarrow ; \\
\text { RET4 } \downarrow ; \text { Ig Kapa } \downarrow ; \\
\text { Ig Gama } \downarrow ; H P T \downarrow ; \\
\text { APOA } 1 \downarrow ; \text { A } 1 \text { AG } 2 \downarrow ; \\
\text { TTHY monomer } \uparrow ; \\
\text { TETN } \uparrow ; \text { APO } \uparrow ; \\
\text { A1AT } \uparrow ; A L B U \uparrow ;\end{array}$ & $\begin{array}{l}\text { Retinoid trans- } \\
\text { port }\end{array}$ & {$[50]$} & - \\
\hline 2007 & $\begin{array}{l}54 \text { first-episode SCZ; } \\
24 \text { IPS; } 70 \text { CTR }\end{array}$ & $\begin{array}{l}\text { H-NMR and SELDI- } \\
\text { TOF-MS }\end{array}$ & $\begin{array}{l}\text { Paranoid schizo- } \\
\text { phrenia; Pro- } \\
\text { dromal state of } \\
\text { psychosis }\end{array}$ & Drug naive & - & $\begin{array}{l}\text { VGF (VGF23-62) } \\
\text { peptide } \uparrow ; T T H Y \downarrow\end{array}$ & Metabolism & {$[51]$} & $\begin{array}{l}\text { Significant differences between CTR } \\
\text { and SCZ; no significant differences } \\
\text { between IPS and CTR, and IPS to SCZ }\end{array}$ \\
\hline 2007 & $\begin{array}{l}10 \text { first-episode SCZ; } \\
10 \text { CTR }\end{array}$ & $\begin{array}{l}\text { label-free nano-LC } \\
\text { MS }^{\mathrm{E}}\end{array}$ & $\begin{array}{l}\text { Paranoid schizo- } \\
\text { phrenia }\end{array}$ & Drug naive & Total ID: 77 & - & - & {$[52]$} & $\begin{array}{l}\text { Clear difference between CTR and } \\
\text { SCZ observed in PLS-DA scores }\end{array}$ \\
\hline 2008 & $41 \mathrm{SCZ} ; 40 \mathrm{CTR}$ & SELDI-TOF-MS & $\begin{array}{l}\text { First episode para- } \\
\text { noid schizophrenia } \\
\text { or Brief psychotic } \\
\text { disorder }\end{array}$ & Drug naive & Total ID: 1 & APOA $1 \downarrow$ & $\begin{array}{l}\text { Neuronal and } \\
\text { glia metabolism }\end{array}$ & {$[40]$} & $\begin{array}{l}\text { Also decreased in the liver, RBC, se- } \\
\text { rum and post-mortem brain samples }\end{array}$ \\
\hline 2010 & $\begin{array}{l}17 \text { first-episode SCZ; } \\
10 \text { CTR }\end{array}$ & $\begin{array}{l}\text { 2-DE/MALDI-TOF/ } \\
\text { TOF }\end{array}$ & $\begin{array}{l}\text { Paranoid schizo- } \\
\text { phrenia }\end{array}$ & $\begin{array}{l}\text { Atypical Antipsy- } \\
\text { chotics }\end{array}$ & Total ID: 6 & $\begin{array}{l}\text { APOE } \uparrow ; \text { PTGDS } \uparrow ; \\
\text { APOA } 1 \uparrow ; \text { TTHY } \downarrow ; \\
\text { TGFR } 1 \downarrow ; \text { CCDC } 3 \downarrow ;\end{array}$ & $\begin{array}{l}\text { Lipid metabo- } \\
\text { lism }\end{array}$ & [53] & $\begin{array}{l}540 \text { protein spots in SCZ 2-DE; } 542 \text { in } \\
\text { CTR; } 468 \text { matched spots }\end{array}$ \\
\hline 2012 & $\begin{array}{l}11 \mathrm{SCZ} ; 20 \mathrm{AD} ; 20 \\
\text { CTR }\end{array}$ & SELDI-TOF-MS & $\begin{array}{l}\text { Sporadic Al- } \\
\text { zheimer's Disease; } \\
\text { Schizophrenia }\end{array}$ & $\begin{array}{l}\text { Neuroleptics and/ } \\
\text { or antipsychotics }\end{array}$ & $\begin{array}{l}\text { Total ID: } 15 \mathrm{~A} \beta- \\
\text { peptides }\end{array}$ & sAPPa $\uparrow ; A \beta 1-42 \downarrow$ & $\begin{array}{l}\text { Neuronal plastic- } \\
\text { ity and survival }\end{array}$ & [54] & - \\
\hline
\end{tabular}

SCZ: Schizophrenia; CTR: Control; LC: Liquid chromatography; MS: Mass Spectrometry; TOF: Time-of-flight; 2-DE: Two-dimensional gel electrophoresis; MALDI: Matrix-assisted laser desorption/ionization;

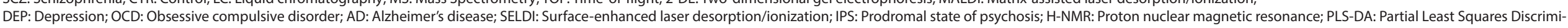
nant Analysis 
Given all this, CSF is a truly valuable source of information from where many potential biomarkers may arise, and of clues to understand the pathophysiology of SCZ, as it is documented in the described studies. Nonetheless, we believe there is still space for the non-targeted large screening approach in the CSF especially due to the constant improvement of the mass spectrometry field. Even so, this fluid does not meet entirely the definition of a good fluid for routine clinical evaluations because its collection is invasive and the amount of sample is relatively small [61]; the study and validation of possible biomarker candidates will probably be translated to more readily available biological fluids.

\section{Biomarker discovery in Peripheral fluids}

For over a decade peripheral fluids' analyses, for disease investigation and biomarker discovery in particular, have increased in the psychiatric field [12]. As shown in Table 2 , blood-based analysis account for the majority of such studies, especially with the analysis of serum and plasma, although blood cells' analysis is growing in interest (Table 3) [74]. The rationale behind this is that, even if psychiatric disorders are brain diseases, its consequences can be detected throughout the entire body; and, most importantly, the access to fluids like blood is considerably easier than the access to the living brain or even to CSF.

It is a long standing fact that there is strong integration of brain and a variety (if not all) of physiological conditions altering the contents of body fluids, where the classic example is the "fight-or-flight reflex" [75] in which there is a strong interplay between the hypothalamic-pituitary-adrenal axis. It has been demonstrated that there are dynamic changes correlating changes in brain and blood and vice-versa $[47,74]$, and, in the case of SCZ, some changes in hormones, cytokines or growth factors can be replicated both in brain and blood stream $[74,76]$.

This whole-body approach of the biology of psychiatric disorders is starting to provide some answers; in recent studies it is stated that molecular signatures may be found in the periphery, especially in circulating blood, as are the examples of studies for schizophrenia $[77,78]$, major depressive disorder [79], and bipolar disorder [80].

In summary, peripheral fluids present themselves as extremely valuable for psychiatric research and biomarker discovery and validation, once molecular changes due to the disease causes, chronicity or drug responses, for instance in proteins' levels or PTM patterns, may be measured directly in the blood (Table 2 and 3), or even in less conventional fluids as saliva or sweat (Table 3 ). The collection of these fluids presents the valuable advantage of being non-invasive (urine, saliva, sweat, tears...) or minimally invasive (blood), allowing for multiple collections and the collection of meaningful amounts for the analyses to be performed. On the other hand, these fluids also present challenges, such as the extremely high dynamic range of plasma or serum, where a dozen of proteins represent more than $90 \%$ of the protein content; the more laborious procedure to obtain pure blood cell specimens [81]; or the still not standardized collection of fluids like saliva, sweat or tears [82-84].

Given all this, an extensive search for SCZ mass spectrometry-based proteomic studies in peripheral circulating fluids was performed. On Table 2 are presented the studies published on blood serum and plasma, spanning from 2006; after this search 7 studies on serum of patients with SCZ and 6 on plasma were found. The preferred quantitative method of analysis of the serum samples was label-free MS, using LC-MS ${ }^{\mathrm{E}}$ [62-64] or MS1 signal intensity [6567]. On the other hand, from the 6 studies in plasma, 5 used 2-DE-MS analysis [50, 69-72] and one study using targeted mass spectrometry MRM technique to quantify 42 plasma proteins [73].

As expected, some of the studies used depletion of the most intense proteins prior to the analysis $[64,65$, 68]; some studies also focused on PTM analysis, namely phosphoproteins and differential phosphorylation patterns $[64,67]$. Zhou et al focused on the peptidome of serum by using magnetic beads to capture the peptides, identifying 10 altered peptides, one of which being identified as a fragment of fibrinopeptide $\mathrm{A}$ with a receiver operating characteristic (ROC) analysis showing an area under the curve of 0.981 between SCZ and controls, and 0.999 for schizophrenia and other chronic diseases [66]. Al Awan and colleagues prepared an integrative study, analyzing proteomics and metabolomics data suggesting a profile signature of the pathology found in serum [67].

Mass spectrometry proteomics studies of SCZ using less conventional fluids as specimens for analysis are presented on Table 3. The use of blood cells, for instance, has the advantage of circumventing the dynamic range issue of serum and plasma. Using such methods total populations of peripheral blood mononuclear cells (PBMC), specific lymphocytes subpopulations as T-cells (both stimulated or unstimulated), or red blood cells (RBC) obtained from the blood stream of SCZ patients have already been studied. $[41,85,86]$ One study using saliva [87] and another using sweat [88] have already been performed in the context of SCZ proteomics.

Red blood cells are an easily accessible cell population of the blood stream, and taking advantage of it Prabakaran et al analyzed RBC proteins using 2D-DIGE methodology, being able to find 8 altered proteins, 4 of which related to oxidative stress, corroborating earlier findings in post-mortem brain tissue and validating blood cells as good specimens for the search for SCZ biomarkers [41].

Studying T-cells from minimally medicated SCZ patients $\alpha$-defensins were found altered and able to discriminate the 2 groups (SCZ and control) in a PCA analyses; this differential expression was further validated by an ELISA assay finding the up-regulation of $\alpha$-defensins both in affected and unaffected monozygotic twins, indicating these 
Table 2. Proteomic studies of schizophrenia and schizophrenia biomarker discovery using mass spectrometry in blood serum and plasma.

\begin{tabular}{|c|c|c|c|c|c|c|c|c|c|}
\hline Year & $\begin{array}{l}\text { Number of } \\
\text { Samples }\end{array}$ & Method & Diagnosis & Treatment & No. proteins & Altered Proteins & $\begin{array}{l}\text { Altered } \\
\text { Pathways }\end{array}$ & Reference & Observations \\
\hline \multicolumn{10}{|c|}{ SERUM } \\
\hline 2007 & $\begin{array}{l}22 \text { first episode } \\
\text { SCZ; } 23 \text { CTR }\end{array}$ & Label-free LC-MSE & $\begin{array}{l}\text { Paranoid } \\
\text { schizophrenia }\end{array}$ & - & $\begin{array}{l}\text { Total ID: } 1709 \\
\text { (50\% Conf); } 232 \\
\left(95 \% \text { Conf }{ }^{*}\right)\end{array}$ & $\begin{array}{l}\text { zinc finger, BTB domain-containing } \\
\text { protein } 38 \text { less abundant; APOA } 1 \\
\text { most abundant }\end{array}$ & - & [62] & Technical paper \\
\hline 2010 & $\begin{array}{l}22 \text { first-episode } \\
\text { drug-naive SCZ; } \\
33 \text { CTR }\end{array}$ & $\begin{array}{l}\text { Label-free nano } \\
\text { UPLC-MSE }\end{array}$ & $\begin{array}{l}\text { Paranoid } \\
\text { schizophrenia }\end{array}$ & Drug naive & $\begin{array}{l}\text { Total ID: } 1411 \\
\text { significantly } \\
\text { different: } 10\end{array}$ & $\begin{array}{l}\text { CD5L } \downarrow ; \text { IGHM } \downarrow ; \text { F13B } \downarrow ; \\
\text { TRFE } \downarrow ; \text { APOD } \downarrow ; \text { APOA } 1 \downarrow ; \\
\text { FETUA } \downarrow ; \text { APOA } 4 \downarrow ; \\
\text { APOA2 } \downarrow ; \text { APOC1 } \downarrow\end{array}$ & $\begin{array}{l}\text { Lipid metabo- } \\
\text { lism; molecu- } \\
\text { lar transport; } \\
\text { immune } \\
\text { response }\end{array}$ & [63] & - \\
\hline 2012 & $\begin{array}{l}20 \text { first-episode } \\
\text { drug-naive SCZ; } \\
20 \text { CTR }\end{array}$ & $\begin{array}{l}\text { Depleted MARS- } \\
14 \\
\text { IMAC + LC-MSE }\end{array}$ & $\begin{array}{l}\text { Paranoid } \\
\text { schizophrenia }\end{array}$ & Drug naive & $\begin{array}{l}\text { Detected: } 694 ; \\
\text { Total ID: } 312 ; \\
\text { Significantly } \\
\text { different: } 35 ; \\
\text { Phospho } \\
\text { altered: } 72\end{array}$ & 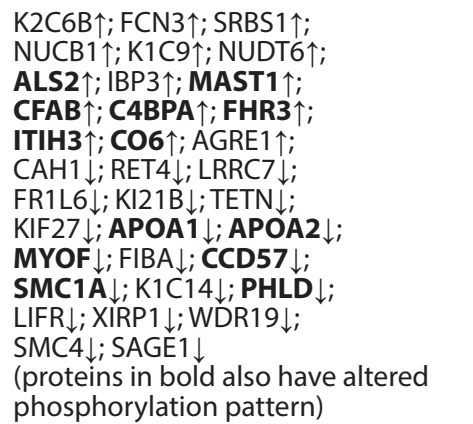 & $\begin{array}{l}\text { Acute phase; } \\
\text { Complement } \\
\text { and coagula- } \\
\text { tion system; } \\
\text { Immune } \\
\text { Response }\end{array}$ & [64] & $\begin{array}{l}\text { Of the } 72 \text { proteins showing } \\
\text { phosphorylation changes, } \\
59 \text { showed no significant } \\
\text { changes in expression level; } \\
\text { FCN3 and RET4 validated } \\
\text { by ELISA }\end{array}$ \\
\hline 2012 & $\begin{array}{l}\text { Proteomics } \\
\text { sample set: } \\
\text { SCZ; } 10 \text { CTR; } \\
\text { Validation } \\
\text { sample set: } 47 \\
\text { SCZ; } 53 \text { CTR }\end{array}$ & $\begin{array}{l}\text { Depleted Label- } \\
\text { free Nano-LC-MS/ } \\
\text { MS }\end{array}$ & Schizophrenia & $\begin{array}{l}\text { Proteomic sample set: drug- } \\
\text { naïve; Validation sample set: } \\
29 \text { drug-naive; } 18 \text { drug- } \\
\text { naive during } 8 \text { weeks; }\end{array}$ & $\begin{array}{l}\text { Total ID: 1344; } \\
192 \text { used for } \\
\text { PLS-DA ( } 27 \text { SCZ- } \\
\text { related) }\end{array}$ & 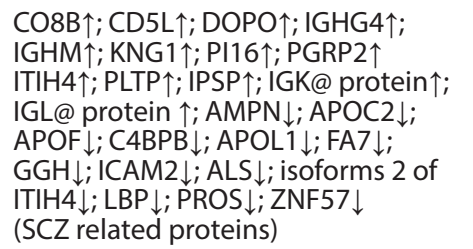 & $\begin{array}{l}\text { Complement } \\
\text { cascade } \\
\text { pathway }\end{array}$ & [65] & $\begin{array}{l}\text { Validation set: were divided } \\
\text { in three groups and received } \\
\text { four weeks treatment with } \\
\text { clozapine ( } 26 \text { patients); } \\
\text { chlorpromazine ( } 15 \text { patients) } \\
\text { or other drugs such as ris- } \\
\text { peridone ( } 6 \text { patients) }\end{array}$ \\
\hline 2014 & $\begin{array}{l}\text { Model: } 166 \text { SCZ; } \\
\text { 201 CTR; } \\
\text { Validation: } 76 \\
\text { SCZ; } 103 \text { CTR } \\
\text { Test group: } 44 \\
\text { SCZ; } 41 \text { CD }\end{array}$ & $\begin{array}{l}\text { Magnetic beads } \\
\text { for peptides } \\
\text { MALDI-TOF/TOF- } \\
\text { MS }\end{array}$ & $\begin{array}{l}\text { Schizophre- } \\
\text { nia, Chronic } \\
\text { diseases: } 29 \\
\text { hypertension; } \\
12 \text { diabetes }\end{array}$ & Drug naive & $\begin{array}{l}\text { Total ID: } 10 \text { al- } \\
\text { tered peptides }\end{array}$ & $\begin{array}{l}\text { Fragment of Fibrinopeptide A } \mathrm{m} / \mathrm{z} \text { : } \\
1206.58 \\
\text { AUC of Roc above } 0.98\end{array}$ & - & [66] & - \\
\hline 2015 & $26 \mathrm{SCZ} ; 26 \mathrm{CTR}$ & $\begin{array}{l}\text { C8 magnetic } \\
\text { beads or C18/ } \\
\text { TiOtips MALDI- } \\
\text { TOF-MS }\end{array}$ & Schizophrenia & $\begin{array}{l}\text { Olanzapine; Clozapine; } \\
\text { Aripiprazole; Flupentixol; } \\
\text { Haloperidol; Zuclopenthixol; } \\
\text { Promethazine; Quetiapine; } \\
\text { Risperidone;Paliperidone; } \\
\text { Flupenthixol; Hydroxyzin; } \\
\text { Levomepromazine; Melper- } \\
\text { one; Amisulprid }\end{array}$ & $\begin{array}{l}\text { Total Detected: } \\
\text { 94; Signifi- } \\
\text { cantly different: } \\
11 \text { protein ions } \\
\text { from TiO; and } 5 \\
\text { from C8 }\end{array}$ & $\begin{array}{l}\mathrm{m} / \mathrm{z} 3177 \text { suggested to be frag- } \\
\text { ment of Apolipoprotein } A 1\end{array}$ & - & [67] & - \\
\hline 2015 & $\begin{array}{l}44 \mathrm{SCZ} ; 26 \mathrm{DP} ; \\
40 \mathrm{CTR}\end{array}$ & $\begin{array}{l}\text { IMAC30 } \\
\text { SELDI-TOF-MS and } \\
\text { MALDI-TOF/TOF }\end{array}$ & $\begin{array}{l}\text { Schizophrenia, } \\
\text { Depression }\end{array}$ & Drug naive & $\begin{array}{l}\text { Significantly } \\
\text { different: } 91 \\
\text { protein peaks }\end{array}$ & $\mathrm{N}$-terminal fragment of fibrinogen $\downarrow$ & - & [68] & \\
\hline
\end{tabular}

International Journal of Clinical Neurosciences and Mental Health 2017; 4(Suppl. 3):S05 
Table 2. Proteomic studies of schizophrenia and schizophrenia biomarker discovery using mass spectrometry in blood serum and plasma. (cont.)

\begin{tabular}{|c|c|c|c|c|c|c|c|c|c|}
\hline Year & $\begin{array}{l}\text { Number of } \\
\text { Samples }\end{array}$ & Method & Diagnosis & Treatment & No. proteins & Altered Proteins & Altered Pathways & Reference & Observations \\
\hline \multicolumn{10}{|c|}{ PLASMA } \\
\hline 2006 & $19 \mathrm{SCZ}$ & $\begin{array}{l}\text { 2-DE/MALDI- } \\
\text { MS }\end{array}$ & Schizophrenia & Chlorpromazine & Total ID: 56 & TTHY tetramer $\uparrow$ & - & [50] & $\begin{array}{l}\text { Responders vs non-responders in } \\
\text { pre and post-treatment }\end{array}$ \\
\hline 2006 & 22 SCZ; 20 CTR & $\begin{array}{l}\text { 2-DE/ MALDI- } \\
\text { TOF-MS }\end{array}$ & Schizophrenia & Clozapine & $\begin{array}{l}\text { Total ID: } 66 ; \\
\text { Significantly } \\
\text { different: } 7\end{array}$ & $\begin{array}{l}\text { HPT- } \alpha 2 \text { chain } \uparrow ; \text { HPT- } \beta \text { chain } \uparrow ; \\
\text { A1AT } \uparrow ; \text { CFAB } \uparrow ; \text { APOA4 } \uparrow ; \\
\text { APOA } 1 \downarrow ; \text { TTHY } \downarrow\end{array}$ & $\begin{array}{l}\text { Inflammatory, Im- } \\
\text { mune response }\end{array}$ & [69] & $\begin{array}{l}\text { To exclude drug treatment effect, } \\
\text { plasma from } 11 \text { SCZ patients was } \\
\text { collected before medication and } \\
\text { after } 2 \text { months of medical treat- } \\
\text { ment (clozapine) }\end{array}$ \\
\hline 2007 & 25 SCZ; 9 CTR & $\begin{array}{l}\text { 2-DE/MALDI- } \\
\text { MS }\end{array}$ & Schizophrenia & $\begin{array}{l}8 \text { patients w/ Chlor- } \\
\text { promazine; } 8 \text { pa- } \\
\text { tients } \mathrm{w} / \text { Clozapine }\end{array}$ & Total ID: 7 & APOA $1 \downarrow$ & Lipoprotein & [70] & $\begin{array}{l}\text { Adult male Sprague-Dawley } \\
\text { rats: } 9 \text { rats w/ Clozapine; } 9 \text { rats w/ } \\
\text { Chlorpromazine; } 8 \text { rats received } \\
\text { ddH O; Total proteins ID: } 29 \text {; } \\
\text { Significantly different: } 18 \text {; APOA1, } \\
\text { APOA4, APOAE } \uparrow \text { w/ Chlorproma- } \\
\text { zine } \\
\text { (negative control) }\end{array}$ \\
\hline 2007 & $42 \mathrm{SCZ} ; 46$ CTR & $\begin{array}{l}\text { 2-DE/MALDI- } \\
\text { MS }\end{array}$ & Schizophrenia & Chlorpromazine & $\begin{array}{l}\text { Total ID: } 20 \text {; } \\
\text { significantly } \\
\text { different: } 6\end{array}$ & $\begin{array}{l}\mathrm{HPT} \uparrow ; \mathrm{A} 1 \mathrm{AT} \uparrow ; \mathrm{SAMP} \uparrow ; \mathrm{AMBP} \uparrow ; \\
\mathrm{ANT} 3 \uparrow ; \mathrm{VTDB} \uparrow\end{array}$ & $\begin{array}{l}\text { Inflammatory, Im- } \\
\text { mune response }\end{array}$ & [71] & - \\
\hline 2014 & $\begin{array}{l}80 \text { first-episode } \\
\text { SCZ }\end{array}$ & $\begin{array}{l}\text { 2-DE/MALDI- } \\
\text { TOF/TOF }\end{array}$ & Schizophrenia & Risperidone & $\begin{array}{l}\text { Total ID and } \\
\text { altered: } 18\end{array}$ & $\begin{array}{l}\text { APOA } 1 \uparrow ; \mathrm{C} 4 \mathrm{~B} \uparrow ; \mathrm{CFB} \uparrow ; \mathrm{NEB} \uparrow ; \\
\mathrm{C} 8 \mathrm{~B} \uparrow ; \mathrm{ZN} 185 \uparrow ; \mathrm{PLMN} \uparrow ; \\
\mathrm{HEMO} \uparrow ; \mathrm{HNMT} \uparrow ; \mathrm{GBP} 1 \uparrow ; \\
\mathrm{FGG} \uparrow ; \mathrm{TRFE} \uparrow ; \mathrm{ALEX} \downarrow ; \mathrm{RET} 4 \downarrow \\
\mathrm{K} 1 \mathrm{C} 9 \downarrow ; \mathrm{K} 2 \mathrm{C} 1 \downarrow ; \mathrm{VINC} \downarrow ; \mathrm{GELS} \downarrow\end{array}$ & Metabolism & [72] & $\begin{array}{l}\text { Investigate changes in protein } \\
\text { expression before and after treat- } \\
\text { ment }\end{array}$ \\
\hline 2016 & $\begin{array}{l}29 \mathrm{SCZ} ; 93 \mathrm{CTR} ; \\
25 \mathrm{BD}\end{array}$ & $\begin{array}{l}\text { nano-LC-MRM- } \\
\text { MS }\end{array}$ & $\begin{array}{l}\text { Schizophrenia, } \\
\text { Bipolar disorder }\end{array}$ & $\begin{array}{l}\text { Quetiapine, Ris- } \\
\text { peridone, Amisul- } \\
\text { pride, Aripiprazole, } \\
\text { Haloperidol, Anti- } \\
\text { depressant (SCZ); } \\
\text { Lithium, Bupropion, } \\
\text { Valdoxan, Lamotri- } \\
\text { gene, Valproic acid, } \\
\text { Quetiapine, Antide- } \\
\text { pressant (BD) }\end{array}$ & $\begin{array}{l}\text { Total ID: } 42 ; \\
\text { significantly } \\
\text { different: } 19\end{array}$ & $\begin{array}{l}\text { ANT3; APOA1; APOA2; APOA4; } \\
\text { APOC1; APOC2; APOC3; } \\
\text { APOC4; APOL1; C1QC; CFB; } \\
\text { C3; F13B; FCN3; HSP70 escort } \\
\text { protein 2; HRG; KLKB1; PEDF; } \\
\text { RET4 } \\
\text { (Patients - SCZ and BD vs. } \\
\text { Control) }\end{array}$ & - & [73] & $\begin{array}{l}\text { Significant dissimilarities } \\
\text { between BD and SCZ patients: } \\
\text { A2AP, ANT3, APOB, APOD } \\
\text { and APOF }\end{array}$ \\
\hline
\end{tabular}

*Conf: Confidence of Identification. For other abbreviations see Table 1 footnotes. 


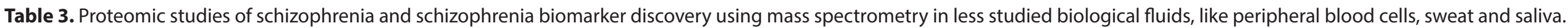

\begin{tabular}{|c|c|c|c|c|c|c|c|c|c|}
\hline Year & $\begin{array}{l}\text { Number of } \\
\text { Samples }\end{array}$ & Method & Diagnosis & Treatment & No. proteins & Altered Proteins & Altered Pathways & Reference & Observations \\
\hline $\begin{array}{l}2014 \\
\text { (Saliva) }\end{array}$ & $\begin{array}{l}32 \mathrm{SCZ} ; 17 \mathrm{BD} ; 31 \\
\mathrm{CTR} \text { (smokers and } \\
\text { non-smokers) }\end{array}$ & $\begin{array}{l}\text { Label-free } \\
\text { peak intensity } \\
\text { HPLC-ESI-MS }\end{array}$ & $\begin{array}{l}\text { Schizophrenia, } \\
\text { Bipolar disorder }\end{array}$ & - & Total ID: 8 & $\begin{array}{l}\text { DEF1 } \uparrow ; \text { a-defensin- } 2 \uparrow ; \text { DEF3 } \uparrow ; \\
\text { DEF4 } \uparrow ; \text { S10AC } \uparrow ; C \text { CSTA } \uparrow ; C \text { CSTB gluta- } \\
\text { thionyl } \uparrow ; C S T B \text { cysteinyl } \uparrow ; \\
\text { (Patients - SCZ and BD vs Control) }\end{array}$ & Innate Immunity & [87] & $\begin{array}{l}\text { No statistically } \\
\text { significant observed } \\
\text { between SCZ and } \\
\text { BD groups }\end{array}$ \\
\hline $\begin{array}{l}2012 \\
\text { (Sweat) }\end{array}$ & $23 \mathrm{SCZ} ; 55 \mathrm{CTR}$ & $\begin{array}{l}\text { Label-free } \\
\text { spectral } \\
\text { counting } \\
\text { LC-MS/MS; } \\
\text { MRM-MS }\end{array}$ & Schizophrenia & $\begin{array}{l}\text { Risperidone; Olan- } \\
\text { zapine; Quetiapine; } \\
\text { Clozapine; Paroxetine; } \\
\text { Escitalopram; Loraz- } \\
\text { epam; Benztropine }\end{array}$ & $\begin{array}{l}\frac{1 \text { st set Total ID: }}{150 ;} \\
2^{\text {nd }} \text { set } \\
\text { Total ID: } 185 ; \\
\text { MRM: } 30\end{array}$ & 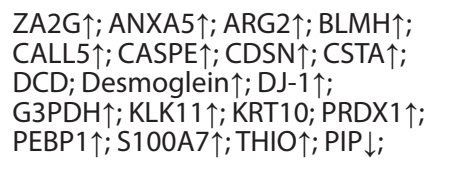 & $\begin{array}{l}\text { Metabolic process; } \\
\text { Biological regulation; } \\
\text { Development process; } \\
\text { Multicellular organis- } \\
\text { mal process; Response } \\
\text { to stimulus }\end{array}$ & [88] & $\begin{array}{l}\text { Altered protein: MRM } \\
\text { results for sweat pep- } \\
\text { tides/proteins chosen } \\
\text { from Scaffold list after } \\
\text { LC-MS/MS of } 2^{\text {nd }} \text { set of } \\
\text { pooled samples }\end{array}$ \\
\hline $\begin{array}{l}2008 \\
\text { (T-Cells) }\end{array}$ & $\begin{array}{l}15 \text { SCZ; } 15 \text { CTR } \\
\text { (SELDI-TOF)/ } \\
6 \text { SCZ; } 18 \text { CTR } \\
\text { (ELISA) }\end{array}$ & $\begin{array}{l}\text { SELDI-TOF MS } \\
\text { and ELISA }\end{array}$ & Schizophrenia & - & $\begin{array}{l}\text { Total ID: } 108 \\
\text { peaks }\end{array}$ & a-defensins $\uparrow$ & Immune response & [86] & - \\
\hline $\begin{array}{l}2011 \\
\text { (PBMC) }\end{array}$ & $\begin{array}{l}19 \mathrm{SCZ} \text { ( } 12 \text { first- } \\
\text { onset; } 7 \text { chroni- } \\
\text { cally ill); } 19 \text { CTR }\end{array}$ & LC-MSE & Schizophrenia & $\begin{array}{l}12 \text { Drug naïve; } 7 \text { Anti- } \\
\text { psychotic treated }\end{array}$ & $\begin{array}{l}\text { Total ID un- } \\
\text { stimulated: } 185 ; \\
\text { Stimulated: } 441 ; \\
\text { Significantly } \\
\text { different: } 19 \\
\text { between drug } \\
\text { naive SCZ and } \\
\text { CTR }\end{array}$ & 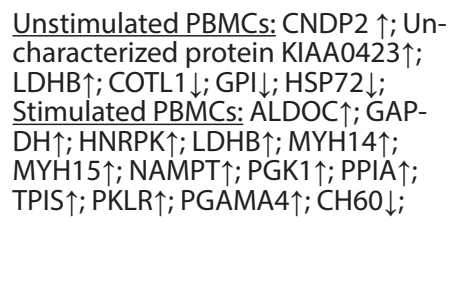 & $\begin{array}{l}\text { Glycolytic pathway, Im- } \\
\text { mune response }\end{array}$ & [85] & $\begin{array}{l}\text { Validation cohort: } \\
8 \text { drug naive; } 7 \\
\text { antipsychotic-treated, } \\
\text { chronically ill patients; } \\
13 \text { CTR }\end{array}$ \\
\hline $\begin{array}{l}2007 \\
\text { (RBC) }\end{array}$ & $\begin{array}{l}20 \text { SCZ (13 treated } \\
\text { / } 7 \text { naïve); } 20 \text { CTR }\end{array}$ & $\begin{array}{l}\text { 2D-DIGE / LC- } \\
\text { MS/MS }\end{array}$ & Schizophrenia & $\begin{array}{l}8 \text { Drug naïve; } 13 \\
\text { antipsychotic-treated } \\
\text { (atypical antipsychotic } \\
\text { medication); }\end{array}$ & $\begin{array}{l}\text { Total ID: } 418 \\
\text { Significantly } \\
\text { different: } 8\end{array}$ & $\begin{array}{l}\text { SBP1 } 1 ; \text { GSTA3 } \uparrow ; \text { PRDX5 } \downarrow ; \text { HS71L } \downarrow ; \\
\text { ALBU } \downarrow ; \text { APOA } 1 \downarrow ; \text { SPTA } 1 \downarrow ; \text { ACTB } \downarrow\end{array}$ & Oxidative Stress & {$[41]$} & - \\
\hline
\end{tabular}

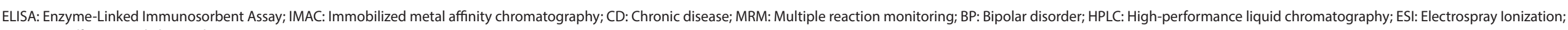
2D-DIGE: Difference gel electrophoresis 
proteins as possible early indicators of SCZ risk [86]. In order to study stimulated and unstimulated PBMCs from drug-naïve SCZ and control individuals, Herberth and colleagues chose a LC-MS ${ }^{\mathrm{E}}$ and were able to quantify hundreds of proteins [85]. From these, 18 proteins were found to be statistically altered between first onset SCZ patients and controls, with more pronounced alterations when the cells are stimulated; this phenotype was found to be rescued when a cohort of chronically ill medicated patients was analyzed, suggesting that these proteins are modulated by medication and may have diagnostic potential in first-episode SCZ patients.

The study using saliva as specimen for the analysis of samples from SCZ and bipolar disorder (BD) found several proteins changed between patients and controls, but was not able to find statistically meaningful differences between SCZ and BD patients [87].

Although studies relating SCZ and sweat odors span back to 1969 [89], and sweat has already been used to analyze the distribution of antipsychotics, like clozapine [90], only one proteomics study was found that searched for SCZ biomarkers in sweat [88]. In this study spectral counting label-free approach was used to compare several pooled samples from SCZ and control individuals and select 30 proteins to be validated by targeted MRM-MS; 17 proteins showed a differential expression of at least 2-fold between the SCZ and control pooled samples.

\section{General Overview and challenges}

Proteins found to be changed in SCZ patients on peripheral fluids were gathered on Figure 1. In this figure, proteins proposed as altered in the published studies were organized by biological fluid; if the same protein was found to be changed in more than one biological fluid it was listed in a "common proteins" column, meaning that there are more evidences for the regulation of those particular proteins in the peripheral fluids of patients with SCZ.

In total, there are dozens of differently expressed proteins which were found changed between the 25 projects analyzed in this review (Tables 1, 2 and 3). From all these proteins only 18 of them were found modulated in at least 2 different fluids; and although in many cases this fact may act as a preliminary validation of the potential of those proteins as SCZ biomarkers, in some of the cases the results in the different studies are not uniform, having opposite differential expressions, as is the example of protein tetranectin which was found upregulated in the CSF study [50] and downregulated in the serum study [64]. On the other hand, some other proteins have been consistently and repeatedly identified as changed in several fluids, as transthyretin which has been found downregulated in CSF [50, 51, 53] and plasma [69], but upregulated in plasma after medication [50].

From the analysis of this integrative Figure 1, it is possible to note that, from 18 "common proteins", 7 be- long to the family of apoliproteins, and these represent some of the most replicated modulated proteins in peripheral fluids in SCZ. Nonetheless, all the other proteins presented in this figure have potential to be further studied, validated and possibly integrated in a panel for SCZ diagnosis, prognosis or even treatment response prediction; even though these large screening approaches still face many challenges.

Overall, this data overview on peripheral biomarkers of SCZ is very encouraging in the pursuit for a proper biomarker panel for the disease. Nonetheless, the fact that SCZ is a very complex and heterogeneous disorder should always be taken into account [91]. Moreover, it is even suggested that further knowledge of the disease pathophysiology and higher stratification of the patients may be needed, where biological and clinical markers may help distinguish different subsets of SCZ patients and may not have the classical diagnostic potential (SCZ versus nonSCZ) $[92,93]$.

Additionally, some important factors are frequently overlooked in screening studies, such as comparing if the candidate proteins show similar patterns in other psychiatric diseases, meaning that those alterations may arise from common phenotypes of the pathologies and not be an indication of the unique traits [93], which is the final goal of a biomarker.

Another challenge in the research of psychosis biomarkers is the sample set and patient recruitment that is necessary for all studies, but in particular for these large screening studies. First-onset drug-naive schizophrenia individuals are the preferred subjects of study and their recruitment has a low rate, leading to longer project duration and consequently longer storage times and higher variability $[94,95]$. On the other hand the recruitment of chronically ill medicated patients is easier but comes with the disadvantage of making it necessary to clearly distinguish drug from disease-related changes, which is not as straightforward as it may seem; it is a factor that is many times disregarded in previous studies, explaining to some extent the low reproducibility of the findings [96].

Thus, the use of well established, well-matched subpools of disease and control subjects, with enough replicates to generate powerful analyses should be used. Another important step is the validation of the interesting findings with different methodologies and most importantly with different and bigger cohorts of individuals. [14].

A primary challenge in the search for biomarkers is the easy access to sufficient amounts of high-quality body fluid [97], for instance the use of CSF. Although it is still the circulating fluid that more closely reflects pathophysiological alterations caused by neurological disorders, and although it is in communication with cerebral extracellular fluid and is less hampered by confounding factors, problems could be associated with CSF sampling as it is still an invasive procedure [97] although it tends to become more routine and safe. 


\section{Unique}

\section{Proteins}

Common

Proteins

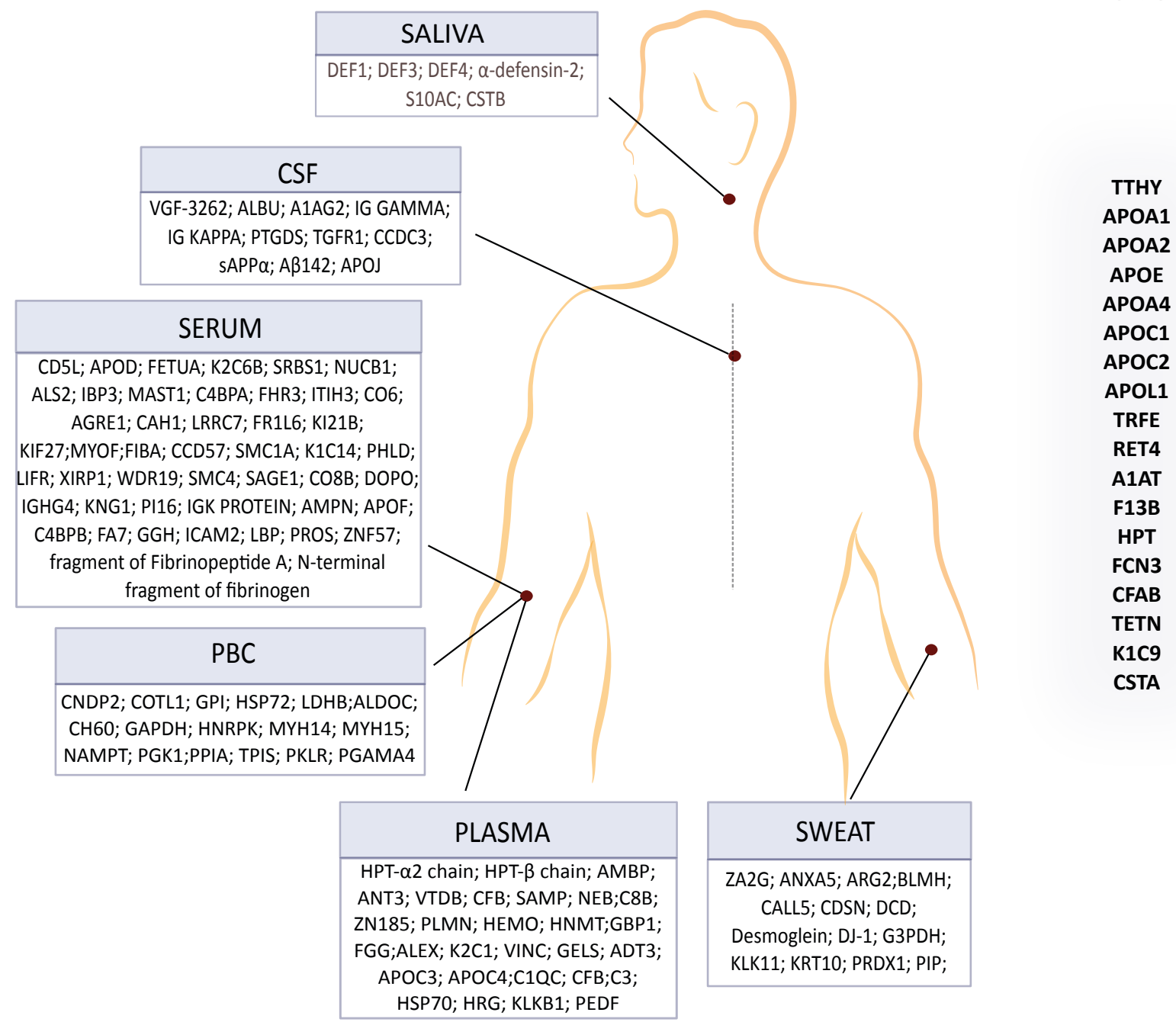

Figure 1. Possible circulating biomarkers. Summary illustration depicting the proteins found altered in the several studies of each fluid. The uniquely altered proteins for each fluid are represented, as well as the proteins found altered in at least 2 different biological fluids.

Moreover, blood collection standardization is a necessary step in any blood study aiming to report findings on potential biomarker. In order to decrease study variation, blood collection protocols should have all identical time of collection, must use the same coagulants and blood processing methods, where these methods should be extensively and accurately described [93]. Furthermore, standardized collection also allows investigators to replicate studies with samples that match the initial pilot data.

In summary, the idea that the establishment of standard operating procedures (SOP) for each step of the process, comprising collection, handling, preparation and storage is appearing as mandatory in order for the results of the different research centers to be integrated and the identification of powerful biomarkers may be reached [98]. Moreover, the publication of entire datasets from these exhaustive proteomic studies, rather than just positive findings, is crucial for the mandatory integration of all information being acquired by the scientific community at the present [14].

\section{Future Perspectives and conclusion}

This review covers a compilation of proteomics studies performed on body fluids of schizophrenia patients using mass spectrometry. Comparative proteomics analysis is extremely important and of the highest clinical interest as it may reveal potential biomarkers for diagnosis and choice of therapy, refining prognosis and treatment prediction. In certain pathologies it is not the presence of certain proteins per se that makes them markers but rather their expression, the alterations in expression as well as their state. Moreover, in many cases it is not just one single protein but a set of proteins that is indicative of a certain disease. In this way, emerging proteomic platforms have facilitated the identification of several biomarker candidates by the simultaneous measurement of thousands of proteins. Before proteomic tools can be routinely used in the clinical laboratory, further work is necessary to enhance the performance and reproducibility of established proteomics approaches. 
Sufficient and high-quality sample, sample collection standardization and type of approach are some of the methodological limits of the existing studies that should be overcome or improved.

The use of multidisciplinary approaches in SCZ studies is appearing as mandatory strategy. Due to the multifactorial picture of schizophrenia, possibly one type of approach is not sufficient to discover one specific biomarker. A combination of imagining techniques, neuropsychology, electroencephalograms (EEGs) and proteomic approaches should be interesting and challenging to identify a multifactorial signature of the disease [95]. Additionally, such a combined approach may help to overcome present difficulties in biomarker discovery such as the issue of antibody availability and lack of comprehensive proteome coverage [95].

The exploration of less classical peripheral fluids, like sweat, saliva or urine, are also starting to arise and will probably be studied more intensely in the future once they present themselves as easily accessible fluids, although still lacking standardization of collection and also of processing. Urine is an easily accessible biological fluid, extensively studied in many fields but still not explored in the proteomics of psychiatry; a possible gap of the investigation in the field.

Since we are in the era of Bioinformatics current studies have been focused on protein expression and protein-protein interactions around certain genes in order to fill the gap between genomics and proteomics [97]. Although most of the published studies are promising, they are based on small sample size, have low power or have not been replicated, which can interfere with further research. Multi-site studies, data sharing, multivariate biomarker studies, and combined use of "omics" data are some alternatives to overcome these methodological limitations [99]. Moreover, there is a critical need for complementing and integrating studies with different profiling methods (proteomics, transcriptomics, metabolomics).

Altogether, mass spectrometry offers the most holistic, integrated system for clinical analysis of patient samples, seeking both known and unknown biomolecules (Tables 1 2 and 3). Mass spectrometers can analyze proteins, peptide fragments, small molecules, antibodies, metabolites, and lipids. This collection, obtainable from a single platform, can generate the total sum of a patient's physiological state needed for quick and proper diagnosis, exact treatment selection, and therapeutic monitoring [23]. The categorization of patients based on proteomic biomarker profiles for optimized treatment is a form of personalized medicine that should be aimed for a nearby future.

\section{Abbreviations}

2D-DIGE: Two-dimensional difference gel electrophoresis; 2-DE: Two-dimensional electrophoresis; BD: Bipolar disorder; CNS: Central nervous system; CNV: Copy number variant; CSF: Cerebrospinal fluid; DNA: Deoxyribonucleic acid; DSM-5: Diagnostic and Statistical Manual of Mental Disorders, 5th edition; ELISA: Enzyme-linked immunosorbent assay; GWAS: Genome wide association studies; ICD - 10: International
Classification of diseases, 10th revision; IEF: Isoelectric focusing; MALDI: Matrix-assisted laser desorption/ionization; MRM: Multiple reaction monitoring; MS: Mass spectrometry; MSE: Mass spectrometry elevated energy; PBMC: Peripheral blood mononuclear cells; PCA: Principal Component analysis; PTM: Post-translational modifications; RBC: Red blood cells; SCZ: Schizophrenia; SDS-PAGE: Sodium dodecyl sulfate polyacrylamide gel electrophoresis; SELDI: Surface-enhanced laser desorption/ionization; WHO: World Health Organization.

\section{Acknowledgments}

This work was financed by the European Regional Development Fund (ERDF) through the COMPETE 2020 - Operational Programme for Competitiveness and Internationalisation and Portuguese national funds via FCT - Fundação para a Ciência e a Tecnologia, I.P., under projects: POCI-01-0145-FEDER-007440, POCI-01-0145-FEDER-016428, PTDC/SAU-NEU/103728/2008, PTDC/NEU-SCC/7051/2014 and POCI-01-0145-FEDER-016795; and by The National Mass Spectrometry Network (RNEM) under the contract REDE/1506/REM/2005. CS was supported by PhD fellowship SFRH/BD/88419/2012, cofunded by the European Social Fund (ESF) through the POCH - Programa Operacional do Capital Humano and national funds via FCT.

\section{Competing interests}

The authors declare no conflict of interest.

References

1. Owen MJ, Sawa A, Mortensen PB. Schizophrenia. Lancet 2016 388(10039):86-97. https://doi.org/10.1016/S0140-6736(15)01121-6

2. Mathers C, Fat DM, Boerma JT. The global burden of disease: 2004 update: World Health Organization; 2008. https://doi.org/10.1016/B978-012373960-5.00335-X

3. McGrath J, Saha S, Chant D, Welham J. Schizophrenia: a concise overview of incidence, prevalence, and mortality. Epidemiologic reviews 2008; 30:67-76. https://doi.org/10.1093/epirev/mxn001

4. Addington J, Heinssen R. Prediction and prevention of psychosis in youth at clinical high risk. Annual review of clinical psychology 2012; 8:269-89. https://doi.org/10.1146/annurev-clinpsy-032511-143146

5. Nascimento JM, Garcia S, Saia-Cereda VM, Santana AG, Brandao-Teles C, Zuccoli GS, et al. Proteomics and molecular tools for unveiling missing links in the biochemical understanding of schizophrenia. Proteomics Clinical applications 2016; 10(12):1148-58. https://doi.org/10.1002/prca.201600021

6. Tandon R, Nasrallah HA, Keshavan MS. Schizophrenia, "just the facts" 5. Treatment and prevention. Past, present, and future. Schizophrenia research 2010; 122(1-3):1-23. https://doi.org/10.1016/j.schres.2010.05.025

7. Association AP. Diagnostic and statistical manual of mental disorders (DSM-5 $\left.{ }^{\circledR}\right)$ : American Psychiatric Pub; 2013. https://doi.org/10.1176/appi.books.9780890425596

8. Organization WH. The ICD-10 classification of mental and behavioural disorders: clinical descriptions and diagnostic guidelines: Geneva: World Health Organization; 1992.

9. Vargas G. Biomarkers in schizophrenia. Biomarkers in medicine 2014; 8(1):1-3 https://doi.org/10.2217/bmm.13.138

10. Owen MJ. New approaches to psychiatric diagnostic classification. Neuron 2014; 84(3):564-71. https://doi.org/10.1016/j.neuron.2014.10.028

11. Schwarz E, Bahn S. Biomarker discovery in psychiatric disorders. Electrophoresis 2008; 29(13):2884-90. https://doi.org/10.1002/elps.200700710 
12. Guest PC, Guest FL, Martins-de Souza D. Making Sense of BloodBased Proteomics and Metabolomics in Psychiatric Research. The international journal of neuropsychopharmacology 2015; pii: pyv138. https://doi.org/10.1093/ijnp/pyv138

13. Biomarkers Definitions Working G. Biomarkers and surrogate endpoints: preferred definitions and conceptual framework. Clinical pharmacology and therapeutics. 2001 Mar;69(3):89-95. https://doi.org/10.1067/mcp.2001.113989

14. Davalieva K, Maleva Kostovska I, Dwork AJ. Proteomics Research in Schizophrenia. Frontiers in cellular neuroscience 2016; 10:18. https://doi.org/10.3389/fncel.2016.00018

15. Schmitt A, Rujescu D, Gawlik M, Hasan A, Hashimoto K, Iceta S, et al. Consensus paper of the WFSBP Task Force on Biological Markers: Criteria for biomarkers and endophenotypes of schizophrenia part II: Cognition, neuroimaging and genetics. The world journal of biological psychiatry : the official journal of the World Federation of Societies of Biological Psychiatry 2016; 17(6):406-28. https://doi.org/10.1080/15622975.2016.1183043

16. Cardno AG, Gottesman II. Twin studies of schizophrenia: from bow-and-arrow concordances to star wars $\mathrm{Mx}$ and functional genomics. American journal of medical genetics 2000; 97(1):12-7. https://doi.org/10.1002/(SICI)1096-8628(200021)97:1<12::AIDAJMG3>3.0.CO;2-U

17. Schizophrenia Working Group of the Psychiatric Genomics C. Biological insights from 108 schizophrenia-associated genetic loci. Nature 2014; 511(7510):421-7. https://doi.org/10.1038/nature13595

18. Malhotra D, Sebat J. CNVs: harbingers of a rare variant revolution in psychiatric genetics. Cell 2012; 148(6):1223-41. https://doi.org/10.1016/j.cell.2012.02.039

19. Kotlar AV, Mercer KB, Zwick ME, Mulle JG. New discoveries in schizophrenia genetics reveal neurobiological pathways: A review of recent findings. European journal of medical genetics 2015; 58(12):704-14. https://doi.org/10.1016/j.ejmg.2015.10.008

20. Baker K, Costain G, Fung WL, Bassett AS. Chromosomal microarray analysis-a routine clinical genetic test for patients with schizophrenia. The lancet Psychiatry 2014; 1(5):329-31. https://doi.org/10.1016/S2215-0366(14)70308-6

21. Bernardo M, Bioque M, Cabrera B, Lobo A, Gonzalez-Pinto A, Pina $\mathrm{L}$, et al. Modelling gene-environment interaction in first episodes of psychosis. Schizophrenia research 2017; pii: S0920-9964(17)30068-3.

22. Matheson SL, Shepherd AM, Laurens KR, Carr VJ. A systematic meta-review grading the evidence for non-genetic risk factors and putative antecedents of schizophrenia. Schizophrenia research 2011; 133(1-3):133-42. https://doi.org/10.1016/j.schres.2011.09.020

23. Duarte TT, Spencer CT. Personalized Proteomics: The Future of Precision Medicine. Proteomes 2016; 4(4). https://doi.org/10.3390/proteomes4040029

24. Graves PR, Haystead TA. Molecular biologist's guide to proteomics. Microbiology and molecular biology reviews: MMBR 2002; 66(1):39-63. https://doi.org/10.1128/MMBR.66.1.39-63.2002

25. Fountoulakis M. Application of proteomics technologies in the investigation of the brain. Mass spectrometry reviews 2004; 23(4):231-58. https://doi.org/10.1002/mas.10075

26. Cox J, Mann M. Quantitative, high-resolution proteomics for data-driven systems biology. Annual review of biochemistry 2011. 80:273-99.

https://doi.org/10.1146/annurev-biochem-061308-093216

27. Ong SE, Mann M. Mass spectrometry-based proteomics turns quantitative. Nature chemical biology 2005; 1(5):252-62. https://doi.org/10.1038/nchembio736
28. Bantscheff M, Lemeer S, Savitski MM, Kuster B. Quantitative mass spectrometry in proteomics: critical review update from 2007 to the present. Analytical and bioanalytical chemistry 2012; 404(4):939-65. https://doi.org/10.1007/s00216-012-6203-4

29. Aebersold R, Mann M. Mass spectrometry-based proteomics. Nature 2003; 422(6928):198-207. https://doi.org/10.1038/nature01511

30. O'Farrell PH. High resolution two-dimensional electrophoresis of proteins. J Biol Chem 1975; 250(10):4007-21.

31. Unlu M, Morgan ME, Minden JS. Difference gel electrophoresis: a single gel method for detecting changes in protein extracts. Electrophoresis 1997; 18(11):2071-7. https://doi.org/10.1002/elps.1150181133

32. Diez R, Herbstreith M, Osorio C, Alzate O. 2-D Fluorescence Difference Gel Electrophoresis (DIGE) in Neuroproteomics. In: Alzate O, editor. Neuroproteomics. Frontiers in Neuroscience. Boca Raton (FL). 2010.

33. Craft GE, Chen A, Nairn AC. Recent advances in quantitative neuroproteomics. Methods 2013; 61(3):186-218. https://doi.org/10.1016/j.ymeth.2013.04.008

34. Shi T, Song E, Nie S, Rodland KD, Liu T, Qian WJ, et al. Advances in targeted proteomics and applications to biomedical research. Proteomics 2016; 16(15-16):2160-82. https://doi.org/10.1002/pmic.201500449

35. Johnston-Wilson NL, Sims CD, Hofmann JP, Anderson L, Shore $\mathrm{AD}$, Torrey EF, et al. Disease-specific alterations in frontal cortex brain proteins in schizophrenia, bipolar disorder, and major depressive disorder. The Stanley Neuropathology Consortium. Molecular psychiatry 2000; 5(2):142-9. https://doi.org/10.1038/sj.mp.4000696

36. English JA, Dicker P, Focking M, Dunn MJ, Cotter DR. 2-D DIGE analysis implicates cytoskeletal abnormalities in psychiatric disease. Proteomics 2009; 9(12):3368-82. https://doi.org/10.1002/pmic.200900015

37. Saia-Cereda VM, Cassoli JS, Schmitt A, Falkai P, Nascimento JM, Martins-de-Souza D. Proteomics of the corpus callosum unravel pivotal players in the dysfunction of cell signaling, structure, and myelination in schizophrenia brains. European archives of psychiatry and clinical neuroscience 2015; 265(7):601-12. https://doi.org/10.1007/s00406-015-0621-1

38. Martins-de-Souza D, Gattaz WF, Schmitt A, Rewerts C, Marangoni $\mathrm{S}$, Novello JC, et al. Alterations in oligodendrocyte proteins, calcium homeostasis and new potential markers in schizophrenia anterior temporal lobe are revealed by shotgun proteome analysis. Journal of neural transmission 2009; 116(3):275-89. https://doi.org/10.1007/s00702-008-0156-y

39. Focking M, Dicker P, English JA, Schubert KO, Dunn MJ, Cotter DR. Common proteomic changes in the hippocampus in schizophrenia and bipolar disorder and particular evidence for involvement of cornu ammonis regions 2 and 3. Arch Gen Psychiatry 2011; 68(5):477-88. https://doi.org/10.1001/archgenpsychiatry.2011.43

40. Huang JT, Wang L, Prabakaran S, Wengenroth M, Lockstone $\mathrm{HE}$, Koethe D, et al. Independent protein-profiling studies show a decrease in apolipoprotein A1 levels in schizophrenia CSF, brain and peripheral tissues. Molecular psychiatry 2008; 13(12):1118-28. https://doi.org/10.1038/sj.mp.4002108

41. Prabakaran S, Wengenroth M, Lockstone HE, Lilley K, Leweke FM, Bahn S. 2-D DIGE analysis of liver and red blood cells provides further evidence for oxidative stress in schizophrenia. Journal of proteome research 2007; 6(1):141-9. https://doi.org/10.1021/pr060308a

42. Wang L, Lockstone HE, Guest PC, Levin Y, Palotas A, Pietsch S, et al. Expression profiling of fibroblasts identifies cell cycle abnormalities in schizophrenia. Journal of proteome research 2010; 9(1):521-7. https://doi.org/10.1021/pr900867x 
43. Deng MY, Lam S, Meyer U, Feldon J, Li Q, Wei R, et al. Frontal-subcortical protein expression following prenatal exposure to maternal inflammation. PloS one 2011; 6(2):e16638. https://doi.org/10.1371/journal.pone.0016638

44. Vercauteren FG, Flores G, Ma W, Chabot JG, Geenen L, Clerens $S$, et al. An organelle proteomic method to study neurotransmission-related proteins, applied to a neurodevelopmental model of schizophrenia. Proteomics 2007; 7(19):3569-79. https://doi.org/10.1002/pmic.200700379

45. Saia-Cereda VM, Cassoli JS, Martins-de-Souza D, Nascimento JM. Psychiatric disorders biochemical pathways unraveled by human brain proteomics. European archives of psychiatry and clinical neuroscience 2017; 267(1):3-17. https://doi.org/10.1007/s00406-016-0709-2

46. Harrison PJ. Using our brains: the findings, flaws, and future of postmortem studies of psychiatric disorders. Biological psychiatry 2011; 69(2):102-3.

https://doi.org/10.1016/j.biopsych.2010.09.008

47. Nascimento JM, Martins-de-Souza D. The proteome of schizophrenia. NPJ schizophrenia 2015; 1:14003. https://doi.org/10.1038/npjschz.2014.3

48. Jiang L, Lindpaintner K, Li HF, Gu NF, Langen H, He L, et al. Proteomic analysis of the cerebrospinal fluid of patients with schizophrenia. Amino acids 2003; 25(1):49-57. https://doi.org/10.1007/s00726-003-0356-6

49. Huang JT, Leweke FM, Oxley D, Wang L, Harris N, Koethe D, et al. Disease biomarkers in cerebrospinal fluid of patients with first-onset psychosis. PLoS medicinev 2006; 3(11):e428.

50. Wan C, Yang Y, Li H, La Y, Zhu H, Jiang L, et al. Dysregulation of retinoid transporters expression in body fluids of schizophrenia patients. Journal of proteome research 2006; 5(11):3213-6. https://doi.org/10.1021/pr0601761

51. Huang JT, Leweke FM, Tsang TM, Koethe D, Kranaster L, Gerth $\mathrm{CW}$, et al. CSF metabolic and proteomic profiles in patients prodromal for psychosis. PloS one 2007; 2(8):e756. https://doi.org/10.1371/journal.pone.0000756

52. Huang JT, McKenna T, Hughes C, Leweke FM, Schwarz E, Bahn S. CSF biomarker discovery using label-free nano-LC-MS based proteomic profiling: technical aspects. Journal of separation science 2007; 30(2):214-25. https://doi.org/10.1002/jssc.200600350

53. Martins-De-Souza D, Wobrock T, Zerr I, Schmitt A, Gawinecka J, Schneider-Axmann T, et al. Different apolipoprotein E, apolipoprotein $\mathrm{A} 1$ and prostaglandin- $\mathrm{H} 2 \mathrm{D}$-isomerase levels in cerebrospinal fluid of schizophrenia patients and healthy controls. The world journal of biological psychiatry: the official journal of the World Federation of Societies of Biological Psychiatry 2010; 11(5):719-28. https://doi.org/10.3109/15622971003758748

54. Albertini V, Benussi L, Paterlini A, Glionna M, Prestia A, Bocchio-Chiavetto L, et al. Distinct cerebrospinal fluid amyloid-beta peptide signatures in cognitive decline associated with Alzheimer's disease and schizophrenia. Electrophoresis 2012; 33(24):3738-44. https://doi.org/10.1002/elps.201200307

55. Greco V, Pieragostino D, Piras C, Aebersold R, Wiltfang J, Caltagirone $\mathrm{C}$, et al. Direct analytical sample quality assessment for biomarker investigation: qualifying cerebrospinal fluid samples. Proteomics 2014; 14(17-18):1954-62. https://doi.org/10.1002/pmic.201300565

56. Filiou MD, Turck CW. General overview: biomarkers in neuroscience research. International review of neurobiology 2011; 101:1-17 https://doi.org/10.1016/B978-0-12-387718-5.00001-8

57. Seehusen DA, Reeves MM, Fomin DA. Cerebrospinal fluid analysis. American family physician 2003; 68(6):1103-8.

58. Merrell K, Southwick K, Graves SW, Esplin MS, Lewis NE, Thulin $\mathrm{CD}$. Analysis of low-abundance, low-molecular-weight serum pro- teins using mass spectrometry. Journal of biomolecular techniques: JBT 2004; 15(4):238-48.

59. Turck CW, Maccarrone G, Sayan-Ayata E, Jacob AM, Ditzen C, Kronsbein $\mathrm{H}$, et al. The quest for brain disorder biomarkers. The journal of medical investigation: JMI 2005; 52 Suppl:231-5.

60. Silva JC, Denny R, Dorschel CA, Gorenstein M, Kass IJ, Li GZ, et al. Quantitative proteomic analysis by accurate mass retention time pairs. Analytical chemistry 2005; 77(7):2187-200. https://doi.org/10.1021/ac048455k

61. Reiber H. Dynamics of brain-derived proteins in cerebrospinal fluid. Clinica chimica acta; international journal of clinical chemistry 2001; 310(2):173-86. https://doi.org/10.1016/S0009-8981(01)00573-3

62. Levin Y, Schwarz E, Wang L, Leweke FM, Bahn S. Label-free LC-MS/MS quantitative proteomics for large-scale biomarker discovery in complex samples. Journal of separation science 2007; 30(14):2198-203. https://doi.org/10.1002/jssc.200700189

63. Levin Y, Wang L, Schwarz E, Koethe D, Leweke FM, Bahn S. Global proteomic profiling reveals altered proteomic signature in schizophrenia serum. Molecular psychiatry 2010; 15(11):1088-100. https://doi.org/10.1038/mp.2009.54

64. Jaros JA, Martins-de-Souza D, Rahmoune H, Rothermundt M, Leweke FM, Guest PC, et al. Protein phosphorylation patterns in serum from schizophrenia patients and healthy controls. Journal of proteomics 2012; 76 Spec No.:43-55. https://doi.org/10.1016/j.jprot.2012.05.027

65. Li Y, Zhou K, Zhang Z, Sun L, Yang J, Zhang M, et al. Label-free quantitative proteomic analysis reveals dysfunction of complement pathway in peripheral blood of schizophrenia patients: evidence for the immune hypothesis of schizophrenia. Molecular bioSystems. 2012; 8(10):2664-71. https://doi.org/10.1039/c2mb25158b

66. Zhou N, Wang J, Yu Y, Shi J, Li X, Xu B, et al. Mass spectrum analysis of serum biomarker proteins from patients with schizophrenia. Biomedical chromatography : BMC 2014; 28(5):654-9. https://doi.org/10.1002/bmc.3084

67. Al Awam K, Haussleiter IS, Dudley E, Donev R, Brune M, Juckel G, et al. Multiplatform metabolome and proteome profiling identifies serum metabolite and protein signatures as prospective biomarkers for schizophrenia. Journal of neural transmission 2015; 122 Suppl 1:S111-22. https://doi.org/10.1007/s00702-014-1224-0

68. Ding YH, Guo JH, Hu QY, Jiang W, Wang KZ. Protein Biomarkers in Serum of Patients with Schizophrenia. Cell biochemistry and biophysics 2015; 72(3):799-805. https://doi.org/10.1007/s12013-015-0536-5

69. Yang Y, Wan C, Li H, Zhu H, La Y, Xi Z, et al. Altered levels of acute phase proteins in the plasma of patients with schizophrenia. Analytical chemistry 2006; 78(11):3571-6. https://doi.org/10.1021/ac051916x

70. La YJ, Wan CL, Zhu H, Yang YF, Chen YS, Pan YX, et al. Decreased levels of apolipoprotein A-I in plasma of schizophrenic patients. Journal of neural transmission 2007; 114(5):657-63. https://doi.org/10.1007/s00702-006-0607-2

71. Wan C, La Y, Zhu H, Yang Y, Jiang L, Chen Y, et al. Abnormal changes of plasma acute phase proteins in schizophrenia and the relation between schizophrenia and haptoglobin $(\mathrm{Hp})$ gene. Amino acids 2007; 32(1):101-8. https://doi.org/10.1007/s00726-005-0292-8

72. Song X, Li X, Gao J, Zhao J, Li Y, Fan X, et al. APOA-I: a possible novel biomarker for metabolic side effects in first episode schizophrenia. PloS one 2014; 9(4):e93902. https://doi.org/10.1371/journal.pone.0093902 
73. Knochel C, Kniep J, Cooper JD, Stablein M, Wenzler S, Sarlon $\mathrm{J}$, et al. Altered apolipoprotein $\mathrm{C}$ expression in association with cognition impairments and hippocampus volume in schizophrenia and bipolar disorder. European archives of psychiatry and clinical neuroscience 2016; 267(3):199-212.

https://doi.org/10.1007/s00406-016-0724-3

74. Hayashi-Takagi A, Vawter MP, Iwamoto K. Peripheral biomarkers revisited: integrative profiling of peripheral samples for psychiatric research. Biological psychiatry 2014; 75(12):920-8. https://doi.org/10.1016/j.biopsych.2013.09.035

75. Laborit H. On the mechanism of activation of the hypothalamo--pituitary--adrenal reaction to changes in the environment (the 'alarm reaction'). Resuscitation 1976; 5(1):19-30. https://doi.org/10.1016/0300-9572(76)90017-4

76. Miller BJ, Buckley P, Seabolt W, Mellor A, Kirkpatrick B. Meta-analysis of cytokine alterations in schizophrenia: clinical status and antipsychotic effects. Biological psychiatry 2011; 70(7):663-71. https://doi.org/10.1016/j.biopsych.2011.04.013

77. Schwarz E, Guest PC, Rahmoune H, Harris LW, Wang L, Leweke FM, et al. Identification of a biological signature for schizophrenia in serum. Molecular psychiatry 2012; 17(5):494-502. https://doi.org/10.1038/mp.2011.42

78. Schwarz E, Steiner J, Guest PC, Bogerts B, Bahn S. Investigation of molecular serum profiles associated with predisposition to antipsychotic-induced weight gain. The world journal of biological psychiatry: the official journal of the World Federation of Societies of Biological Psychiatry 2015; 16(1):22-30. https://doi.org/10.3109/15622975.2013.817685

79. Hori H, Sasayama D, Teraishi T, Yamamoto N, Nakamura S, Ota $\mathrm{M}$, et al. Blood-based gene expression signatures of medication-free outpatients with major depressive disorder: integrative genome-wide and candidate gene analyses. Scientific reports 2016; 6:18776. https://doi.org/10.1038/srep18776

80. Tsuang MT, Nossova N, Yager T, Tsuang MM, Guo SC, Shyu $\mathrm{KG}$, et al. Assessing the validity of blood-based gene expression profiles for the classification of schizophrenia and bipolar disorder: a preliminary report. American journal of medical genetics Part B, Neuropsychiatric genetics: the official publication of the International Society of Psychiatric Genetics 2005; 133B(1):1-5.

81. Palmirotta R, De Marchis ML, Ludovici G, Leone B, Savonarola $\mathrm{A}$, Ialongo $\mathrm{C}$, et al. Impact of preanalytical handling and timing for peripheral blood mononuclear cells isolation and RNA studies: the experience of the Interinstitutional Multidisciplinary BioBank (BioBIM). The International journal of biological markers 2012; 27(2):e90-8. https://doi.org/10.5301/JBM.2012.9235

82. Nunes LA, Mussavira S, Bindhu OS. Clinical and diagnostic utility of saliva as a non-invasive diagnostic fluid: a systematic review. Biochemia medica 2015; 25(2):177-92. https://doi.org/10.11613/BM.2015.018

83. Gomez CC, Servidoni Mde F, Marson FA, Canavezi PJ, Vinagre AM, Costa ET, et al. Pulsed direct and constant direct currents in the pilocarpine iontophoresis sweat chloride test. BMC pulmonary medicine 2014; 14:198.

https://doi.org/10.1186/1471-2466-14-198

84. Pucker AD, Ng SM, Nichols JJ. Over the counter (OTC) artificial tear drops for dry eye syndrome. The Cochrane database of systematic reviews 2016; 2:CD009729. https://doi.org/10.1002/14651858.CD009729.pub2

85. Herberth M, Koethe D, Cheng TM, Krzyszton ND, Schoeffmann $\mathrm{S}$, Guest PC, et al. Impaired glycolytic response in peripheral blood mononuclear cells of first-onset antipsychotic-naive schizophrenia patients. Molecular psychiatry 2011; 16(8):848-59. https://doi.org/10.1038/mp.2010.71
86. Craddock RM, Huang JT, Jackson E, Harris N, Torrey EF, Herberth $\mathrm{M}$, et al. Increased alpha-defensins as a blood marker for schizophrenia susceptibility. Molecular \& cellular proteomics: MCP 2008; 7(7):1204-13. https://doi.org/10.1074/mcp.M700459-MCP200

87. Iavarone F, Melis M, Platania G, Cabras T, Manconi B, Petruzzelli $\mathrm{R}$, et al. Characterization of salivary proteins of schizophrenic and bipolar disorder patients by top-down proteomics. Journal of proteomics 2014; 103:15-22. https://doi.org/10.1016/j.jprot.2014.03.020

88. Raiszadeh MM, Ross MM, Russo PS, Schaepper MA, Zhou W, Deng J, et al. Proteomic analysis of eccrine sweat: implications for the discovery of schizophrenia biomarker proteins. Journal of proteome research 2012; 11(4):2127-39. https://doi.org/10.1021/pr2007957

89. Smith K, Thompson GF, Koster HD. Sweat in schizophrenic patients: identification of the odorous substance. Science 1969; 166(3903):398-9. https://doi.org/10.1126/science.166.3903.398

90. Cirimele V, Kintz P, Gosselin O, Ludes B. Clozapine dose-concentration relationships in plasma, hair and sweat specimens of schizophrenic patients. Forensic science international 2000; 107(1-3):289-300. https://doi.org/10.1016/S0379-0738(99)00172-3

91. Sullivan PF, Kendler KS, Neale MC. Schizophrenia as a complex trait: evidence from a meta-analysis of twin studies. Arch Gen Psychiatry 2003; 60(12):1187-92. https://doi.org/10.1001/archpsyc.60.12.1187

92. Sun J, Jia P, Fanous AH, van den Oord E, Chen X, Riley BP, et al. Schizophrenia gene networks and pathways and their applications for novel candidate gene selection. PloS one 2010; 5(6):e11351. https://doi.org/10.1371/journal.pone.0011351

93. Lai CY, Scarr E, Udawela M, Everall I, Chen WJ, Dean B. Biomarkers in schizophrenia: A focus on blood based diagnostics and theranostics. World journal of psychiatry 2016; 6(1):102-17. https://doi.org/10.5498/wjp.v6.i1.102

94. Chan MK, Krebs MO, Cox D, Guest PC, Yolken RH, Rahmoune H, et al. Development of a blood-based molecular biomarker test for identification of schizophrenia before disease onset. Translational psychiatry 2015; 5:e601. https://doi.org/10.1038/tp.2015.91

95. Sabherwal S, English JA, Focking M, Cagney G, Cotter DR. Blood biomarker discovery in drug-free schizophrenia: the contributionof proteomics and multiplex immunoassays. Expert review of proteomics 2016; 13(12):1141-55. https://doi.org/10.1080/14789450.2016.1252262

96. Jordan W, Dobrowolny H, Bahn S, Bernstein HG, Brigadski T, Frodl $\mathrm{T}$, et al. Oxidative stress in drug-naive first episode patients with schizophrenia and major depression: effects of disease acuity and potential confounders. European archives of psychiatry and clinical neuroscience 2016. https://doi.org/10.1007/s00406-016-0749-7

97. Lakhan SE, Kramer A. Schizophrenia genomics and proteomics: are we any closer to biomarker discovery? Behavioral and brain functions: BBF; 5:2.

98. Apweiler R, Aslanidis C, Deufel T, Gerstner A, Hansen J, Hochstrasser D, et al. Approaching clinical proteomics: current state and future fields of application in fluid proteomics. Clinical chemistry and laboratory medicine 2009; 47(6):724-44. https://doi.org/10.1515/CCLM.2009.167

99. Venkatasubramanian G, Keshavan MS. Biomarkers in Psychiatry A Critique. Annals of neurosciences 2016; 23(1):3-5. https://doi.org/10.1159/000443549 